\title{
Inorganic anions as retarders for deep borehole disposal grouts
}

\section{Nicholas C. Collier}

Postdoctoral Research Associate, Deep Borehole Disposal Research Group Immobilisation Science Laboratory, Department of Materials Science \& Engineering, The University of Sheffield, Sheffield, UK (corresponding author: nick.collier@sheffield.ac.uk)

\section{Hector E. Balboa}

MSc Student, Deep Borehole Disposal Research Group, Immobilisation Science Laboratory, Department of Materials Science \& Engineering, The University of Sheffield, Sheffield, UK
Neil B. Milestone

Distinguished Research Fellow, Callaghan Innovation, Lower Hutt, New Zealand

Karl P. Travis

Reader, Deep Borehole Disposal Research Group, Immobilisation Science Laboratory, Department of Materials Science \& Engineering, The University of Sheffield, Sheffield, UK

Deep borehole disposal (DBD) provides an alternative to comparatively shallow mined repository concepts for many high-level radioactive wastes. Filling the annular space around the waste containers with cement grout will support them during placement and seal against ingress of groundwater. The elevated temperature and pressure $\left(\sim 120^{\circ} \mathrm{C}\right.$ and $50 \mathrm{MPa}$ ) will cause acceleration of grout thickening and setting, so retardation is required. The DBD Research Group at The University of Sheffield has developed grouts based on class G oil well cement that use organic retarders, but their presence may increase the solubility of any radionuclides released from the waste packages. New DBD grout formulations using sodium phosphate and sodium borate as inorganic retarders are reported in this paper. To place the wet grout, the onset of thickening needs to be delayed for at least $\mathbf{4} \mathbf{h}$. Sodium borate was found to provide this retardation at $90^{\circ} \mathrm{C}(0.75 \%$ addition $)$ and nearly retarded sufficiently at $120^{\circ} \mathrm{C}(1 \%$ addition). Sodium phosphate did not provide sufficient retardation at either temperature. Neither compounds influenced the phases formed, but may suppress the crystallisation of calcium silicate hydrates. This work demonstrates that the performance of these inorganic materials in this application is inferior to that of organic retarders.

\section{Introduction}

Deep borehole disposal (DBD) provides a potentially superior alternative to comparatively shallow mined repository concepts for the disposal of high-level radioactive wastes, including spent fuel (Arnold et al., 2013; Beswick et al., 2014; Chapman and Gibb, 2003; Gibb, 2010). The DBD concept emplaces and seals individual waste packages within a disposal zone located in the lowest $1-2 \mathrm{~km}$ of boreholes drilled $\sim 5 \mathrm{~km}$ deep into basement rock. This creates significant advantages over disposal in mined repositories a few hundred metres deep, based on features associated with safety, cost or ease of implementation (Gibb, 2010). Sealing and support matrices (SSMs) are being developed for DBD applications (Gibb et al., 2008), and their primary function is to seal individual containers into the disposal zone and provide a barrier to the ingress of saline groundwater to restrict container corrosion. SSMs also provide mechanical support to the container against buckling and, in the event of possible container failure during loading operations, will provide a seal/barrier to any radionuclides leaching into the borehole fluid. The preferred SSM, known as a highdensity support matrix (HDSM), is a lead-based alloy designed to melt at $\sim 190^{\circ} \mathrm{C}$ at the pressure estimated at the bottom of the open borehole $(\sim 30-50 \mathrm{MPa})$. This HDSM produces a matrix with very low permeability and excellent sealing properties. Where the temperature at the container surface does not exceed $\sim 190^{\circ} \mathrm{C}$, there will be insufficient heat to melt the HDSM, so a cementitious grout is recommended (Beswick et al., 2014).
In the construction of hydrocarbon and geothermal wells, BS EN ISO/API class G oil well cements (BSI, 2009) are used to secure the steel casing to the formation after drilling. This also provides a degree of separation between the different fluid chemistries and rock formations through which the borehole passes (Nelson and Guillot, 2006; Taylor, 1997). Post-drilling cementing operations are challenging because of the elevated temperature and pressure, and similar difficulties are encountered in DBD. These conditions are due to

- the local geological environment, where an ambient temperature range of $80-130^{\circ} \mathrm{C}$ would be typical at a depth of $\sim 5 \mathrm{~km}$ (Best, 2003)

- radioactive decay heat from the waste packages

- hydrostatic pressure caused by the head of the borehole fluids $(\sim 30-50 \mathrm{MPa})$.

DBD grout deployment should occur within a few hours of package placement so any temperature rise due to radioactive decay heat will be insignificant during grout placement and setting. Elevated temperature and pressure both accelerate cement hydration, reducing the time for the grout to thicken and set (Bensted, 2008; Jupe et al., 2008; Nelson and Guillot, 2006; Scherer et al., 2010; Shariar and Nehdi, 2014; Taylor, 1997; Zhang et al., 2010). Temperature has more influence over the reaction rate than pressure and also has a greater effect on the composition of the main cement hydrate phases 
formed. The following two factors are used to determine the acceptable performance of DBD grouts.

- The limit of pumpability is reported to be $70 \mathrm{Bc}$ (Bearden units), which is the maximum consistency at which DBD grouts can be pumped (Nelson and Guillot, 2006) and this has also been taken as the maximum consistency at which they will flow around a waste package in the borehole.

- The drilling industry is confident that DBD grout could be delivered to the bottom of a $\sim 5 \mathrm{~km}$ deep borehole in a time of $\sim 4$ h (although options for shorter delivery times are being explored), so this is taken as the minimum time $\left(t_{2}\right)$ required to limit grout consistency to $\leq 70 \mathrm{Bc}$.

The phase composition of the hardened grout is important in terms of the lifetime of the well, where the most durable hydrate phases need to be formed.

Organic retarders have been shown to retard grout thickening sufficiently for use as SSMs in DBD (Collier et al., 2015a, 2015b, 2016) and the grouts produced have desirable properties at high temperature and high pressure. However, organic compounds may complex any radionuclides present and increase their solubility (Bourbon and Toulhoat, 1996; Hakanen and Ervanne, 2006), so their use in nuclear waste repositories a few hundred metres deep has been discouraged. In DBD, any radionuclide release is only likely many years after borehole sealing and the geological barrier re-established, and the elevated temperature and pressure coupled with the high $\mathrm{pH}$ of the cement grout will quickly decompose any organic compounds (Glasser, 1992, 1993). However, to address concerns about this impact on radionuclide solubility, inorganic retarders are also being investigated.

Inorganic cations (such as tin $(\mathrm{Sn})$, zinc $(\mathrm{Zn})$ and lead $(\mathrm{Pb})$ ) and anions (such as borate and phosphate) can retard cement hydration (Odler, 2004; Taylor, 1997), and the majority of studies have focused on the effect of phosphate at atmospheric temperature and pressure (Bénard et al., 2005, 2008; Ltifi et al., 2011; Ma and Brown, 1994). The mechanism by which these inorganic ions retard thickening is not well recorded in the literature; the retardation mechanisms of organic materials has received far more attention and is much more widely reported (Banfill, 1986; Wilding et al., 1984; Young, 1972). For inorganic ions, retardation is likely to be caused by either surface adsorption or the formation of protective layers over the cement grains, which has been demonstrated using lead (Thomas et al., 1981) and zinc (Arliguie et al., 1982). When this happens, the first hydration peak is retarded considerably, extending the period of hydration. There is a paucity of published information covering the use of inorganic retarders at elevated temperature and pressure, making it difficult to assess their applicability in DBD. This may be due to them being less effective or that commercial interests prevent publication of research findings.
The work reported here was focused on the influence of sodium borate and sodium phosphate on the properties of class $G$ oil well cement systems being considered for DBD. Class $G$ cement was used because it is designed for use in hydrocarbon and geothermal well cementing applications at temperatures and pressures similar to those in DBD. The influence of sodium borate and sodium phosphate on rheological properties was investigated at elevated temperature and pressure, and the early-age phase composition was determined to confirm the formation of desirable hydrated phases.

\section{Experimental details}

\section{Materials and sample preparation}

Dyckerhoff API class G HSR (high sulfate resistant) oil well cement (BS EN ISO 10426-1 (BSI, 2009)) partially replaced with silica flour was used to make the grout; the compositions of both are detailed in Tables 1 and 2. To enable the grout to flow through water without dispersion of solid particles, an underwater additive (UCS Pak) was used. The exact composition of this material is unknown because of commercial sensitivity, but it is reported to contain silica and organic compounds. Sodium phosphate (sodium phosphate dibasic heptahydrate, $\mathrm{Na}_{2} \mathrm{HPO}_{4} .7 \mathrm{H}_{2} \mathrm{O}$ ) and sodium borate (disodium tetraborate pentahydrate, $\mathrm{Na}_{2} \mathrm{~B}_{4} \mathrm{O}_{7} .5 \mathrm{H}_{2} \mathrm{O}$ ) were investigated as retarders. Tap water was used to mix the grout, which was performed according to BS EN ISO 10426-1:2009 (BSI, 2009) at a laboratory temperature of $\sim 22^{\circ} \mathrm{C}$ and atmospheric pressure $(\sim 0 \cdot 1 \mathrm{MPa})$. The grout had a density (excluding any retarder) of $1.892 \mathrm{~kg} / \mathrm{m}^{3}$.

Table 1. Oxide composition of class $G$ cement and silica flour

\begin{tabular}{|c|c|c|}
\hline & Class G cement & Silica flour \\
\hline Silicon dioxide $\left(\mathrm{SiO}_{2}\right): \mathrm{wt} \%$ & $21 \cdot 8$ & $99 \cdot 7$ \\
\hline Aluminium oxide $\left(\mathrm{Al}_{2} \mathrm{O}_{3}\right)$ : wt\% & $4 \cdot 2$ & $0 \cdot 10$ \\
\hline Iron oxide $\left(\mathrm{Fe}_{2} \mathrm{O}_{3}\right)$ : wt\% & $5 \cdot 3$ & 0.03 \\
\hline Magnesium oxide (MgO): wt\% & 0.6 & 0.004 \\
\hline Calcium oxide (CaO): wt\% & $64 \cdot 1$ & 0.006 \\
\hline Sulfur trioxide $\left(\mathrm{SO}_{3}\right)$ : wt\% & $2 \cdot 7$ & - \\
\hline Loss on ignition: wt\% & $1 \cdot 2$ & $0 \cdot 10$ \\
\hline Total: wt\% & $99 \cdot 9$ & $99 \cdot 9$ \\
\hline
\end{tabular}

Table 2. Cement phase composition of class $G$ cement

$\begin{array}{lc}\text { Cement phase }^{a} & \text { Phase content: wt\% } \\ \mathrm{C}_{3} \mathrm{~S} & 54 \cdot 4 \\ \beta-\mathrm{C}_{2} \mathrm{~S} & 22 \cdot 3 \\ \mathrm{C}_{3} \mathrm{~A} & 2 \cdot 0 \\ \mathrm{C}_{4} \mathrm{AF} & 16 \cdot 4\end{array}$

${ }^{a}$ Calculated from ASTM C 150/C 150M (ASTM, 2016) and using cement oxide nomenclature: $\mathrm{C}=$ calcium oxide, $\mathrm{S}=$ silicon dioxide, $\mathrm{H}=$ water, $\mathrm{A}=$ aluminium oxide and $\mathrm{F}=$ iron oxide 


\section{Sample analysis}

Grout consistency was measured in a high-pressure hightemperature consistometer. These instruments are used in well cementing to investigate cement grout thickening behaviour under simulated downhole conditions. The consistometer used in this work complied with American Petroleum Institute specification 10A (API, 2010) (synonymous with BS EN ISO 10426-1:2009 (BSI, 2009)). Detailed information concerning the design of the consistometer, sample container, impeller and so on is included in the API specification but, briefly, the sample container had an internal diameter of $74 \mathrm{~mm}$ and was $116 \mathrm{~mm}$ long, the consistometer impeller had an outer diameter of $71 \mathrm{~mm}$ and was $108 \mathrm{~mm}$ long overall, and the impeller rotated continuously at $150 \mathrm{rpm}$. Consistency is measured in terms of Bearden units $(\mathrm{Bc})$, and is related to the torque $(T)$ required to stir the grout during testing by the empirical equation $T=78 \cdot 2+(20 \cdot 02 \times \mathrm{Bc})$. Consistency testing was performed using a linear heating/pressurising regime, increasing from ambient to either $90^{\circ} \mathrm{C}$ or $120^{\circ} \mathrm{C}$ and $50 \mathrm{MPa}$ over $4 \mathrm{~h}$ to simulate the conditions that the grout would experience while being lowered down a borehole. After this $4 \mathrm{~h}$ period, temperature and pressure were maintained until consistency exceeded the upper limit of detection $(100 \mathrm{Bc})$. The times at which specific changes in consistency occurred were recorded; $t_{1}$ was the time at which minimum consistency occurred and $t_{2}$ was the time for consistency to reach $70 \mathrm{Bc}$ (the maximum consistency at which the grout will no longer be able to flow around waste packages). Additionally, the grout should not exceed $70 \mathrm{Bc}$ during mixing because it would not be able to be pumped during deployment. For each grout where $t_{2}$ was greater than $4 \mathrm{~h}$, grout set was checked $24 \mathrm{~h}$ after mixing using Vicat equipment (ASTM C 191-13 (ASTM, 2013)). Cement hydration reactions were investigated using a TAM Air isothermal calorimeter at $85^{\circ} \mathrm{C}$. Once the amounts of retarders that gave acceptable levels of grout consistency had been determined, viscosity and yield stress data were obtained using a Haake VT550 viscometer operating at laboratory temperature and atmospheric pressure. Testing was performed using a rotational vane rotor (Haake FL100 starshaped vane rotor with a diameter of $22 \mathrm{~mm}$ and length of $16 \mathrm{~mm}$ ) in a glass beaker of grout having a diameter of $90 \mathrm{~mm}$ and depth of $100 \mathrm{~mm}$ to represent a continuous medium around the vane (and negate any influence caused by the interface between the grout and the sides of the container). Strain rate was varied between 0 and $25 \mathrm{~s}^{-1}$ and the stress was measured.

The early-age hardened grout composition was investigated by casting samples of the control grout and grouts containing either $2 \%$ (by weight of cement) sodium phosphate or sodium borate, and hydrothermally curing them at $120^{\circ} \mathrm{C}$ for 7,14 and $28 \mathrm{~d}$. After each time interval, hydration was arrested using acetone as a solvent replacement technique (Collier et al., 2008) and the composition was determined by means of X-ray diffraction (XRD) and thermogravimetric analysis/derivative thermogravimetric analysis (TGA/DTG). A Bruker D2 Phaser
X-ray diffractometer was operated between 5 and $90^{\circ} 2 \theta$ at $2 \%$ min and a Perkin Elmer Pyris 1 thermogravimetric analyser was operated using a heating profile of $30-1000^{\circ} \mathrm{C}$ at $10^{\circ} \mathrm{C} / \mathrm{min}$ in flowing nitrogen. Microstructural morphology and elemental distribution were investigated using a Hitachi TM3030 scanning electron microscope (SEM) fitted with an energy dispersive spectrometer (EDX).

Multiple sample runs were made in setting up each analytical test. As many of the tests took longer than $24 \mathrm{~h}$ to set up and perform, making it difficult to obtain multiple analyses of the same sample, the most representative data were selected for inclusion in this paper.

\section{Results}

\section{Wet paste properties}

Consistency plots of grouts containing sodium borate tested at $90^{\circ} \mathrm{C}$ are shown in Figure 1 (increase in pressure is omitted for clarity) and the data from all the tests are summarised in Table 3.

For each grout, after an initial increase in consistency during the first $10 \mathrm{~min}$ of testing $\left(20-25^{\circ} \mathrm{C}\right.$ testing temperature), the consistency decreased with increasing time, temperature and pressure into the range $0-10 \mathrm{Bc}$. Towards the end of the test period, consistency rapidly increased towards $100 \mathrm{Bc}$ (at which point the instrument stopped measuring). In cases where the time to reach $100 \mathrm{Bc}$ was greater than $8 \mathrm{~h}$ (e.g. for the grouts containing $1 \%$ and $2 \%$ sodium borate shown in Figure 1), the experiment was stopped before reaching $100 \mathrm{Bc}$.

For the control grout (without retarder), $t_{2}$ was less than $4 \mathrm{~h}$ $\left(2 \cdot 7 \mathrm{~h}\right.$ and $2.0 \mathrm{~h}$ at $90^{\circ} \mathrm{C}$ and $120^{\circ} \mathrm{C}$ respectively), confirming the need for retardation.

With the use of sodium phosphate, no addition level produced a $t_{2}$ value greater than $4 \mathrm{~h}$ at either $90^{\circ} \mathrm{C}$ or $120^{\circ} \mathrm{C}$. Although

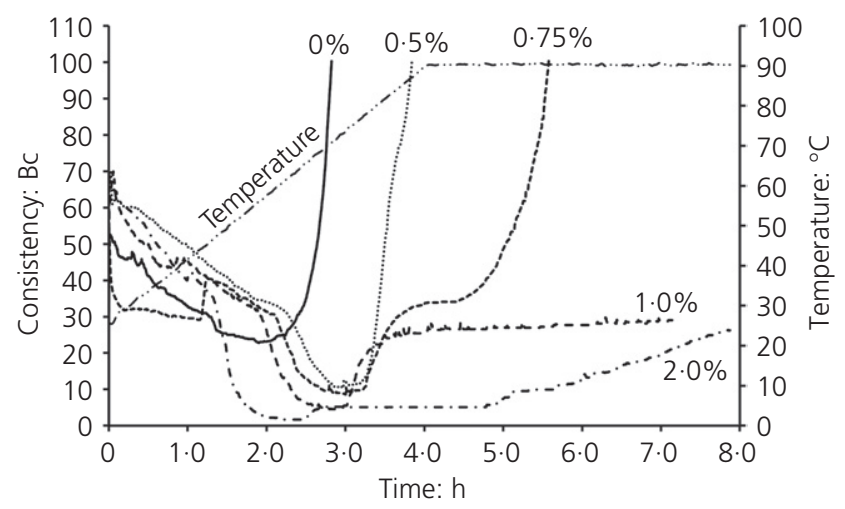

Figure 1. Consistency of grouts containing sodium borate $\left(90^{\circ} \mathrm{C}\right.$ and $50 \mathrm{MPa}$ ) 
Table 3. Summary of consistency results

\begin{tabular}{|c|c|c|c|c|}
\hline \multirow{2}{*}{$\begin{array}{c}\text { Addition: \% } \\
\text { (by weight of cement) }\end{array}$} & \multicolumn{2}{|c|}{$90^{\circ} \mathrm{C}$} & \multicolumn{2}{|c|}{$120^{\circ} \mathrm{C}$} \\
\hline & $t_{1}: h^{\mathrm{a}}$ & $t_{2}: h^{b}$ & $t_{1}: h$ & $t_{2}: \mathrm{h}$ \\
\hline \multicolumn{5}{|l|}{ Control grout } \\
\hline 0.0 & 1.9 & $2 \cdot 7$ & $1 \cdot 5$ & $2 \cdot 0$ \\
\hline \multicolumn{5}{|l|}{ Sodium phosphate grout } \\
\hline 1.0 & - & - & $1 \cdot 8$ & $2 \cdot 6$ \\
\hline $2 \cdot 0$ & $2 \cdot 0$ & $3 \cdot 2$ & 1.4 & $2 \cdot 3$ \\
\hline $3 \cdot 0$ & 1.7 & $3 \cdot 3$ & - & - \\
\hline $4 \cdot 0$ & 1.6 & $2 \cdot 8$ & - & - \\
\hline \multicolumn{5}{|l|}{ Sodium borate grout } \\
\hline 0.5 & $3 \cdot 0$ & $3 \cdot 6$ & - & - \\
\hline 0.75 & $2 \cdot 9$ & $5 \cdot 4$ & - & - \\
\hline $1 \cdot 0$ & $2 \cdot 8$ & $>7 \cdot 1$ & $1 \cdot 5$ & $3 \cdot 9$ \\
\hline $2 \cdot 0$ & $2 \cdot 3$ & $>7.8$ & c & c \\
\hline \multicolumn{5}{|c|}{ Sodium phosphate + Sodium borate grout } \\
\hline $2 \cdot 0+2 \cdot 0$ & - & - & $1 \cdot 1$ & $4 \cdot 4^{d}$ \\
\hline
\end{tabular}

${ }^{\mathrm{a}} t_{1}=$ time at which minimum consistency occurred

${ }^{b_{t_{2}}}=$ time for consistency to reach $70 \mathrm{BC}$

'Paste was too thick to test

${ }^{\mathrm{d} C}$ Consistency was greater than $70 \mathrm{BC}$ after mixing

the results are difficult to interpret (because of the increase in both $t_{1}$ and $t_{2}$ upon adding sodium phosphate compared with the results for the control grout), there was a reduction in $t_{1}$ and generally a reduction in $t_{2}$ as the quantity of sodium phosphate increased. It was visually observed that adding increasing amounts of sodium phosphate caused a reduction in grout viscosity and reduced consistency during mixing.

When increasing amounts of sodium borate were added, $t_{1}$ was reduced and $t_{2}$ increased at $90^{\circ} \mathrm{C}$, with samples containing $\geq 0 \cdot 75 \%$ achieving a $t_{2}$ value greater than $4 \mathrm{~h}$. At $120^{\circ} \mathrm{C}$, the addition of $1 \%$ sodium borate almost achieved a $t_{2}$ of $4 \mathrm{~h}$. However, for grouts containing greater quantities, the initial consistency was so high that it recorded $>100 \mathrm{Bc}$ as soon as testing was begun. Based on the observation that adding sodium phosphate reduced grout thickness, a combination of sodium borate and sodium phosphate was trialled. These results showed that, with the addition of $2 \%$ of each compound, a $t_{2}$ value greater than $4 \mathrm{~h}$ was achieved at $120^{\circ} \mathrm{C}$, but the initial consistency was greater than $70 \mathrm{Bc}$, meaning it could not be used in this application.

In all grouts where $t_{2}$ was greater than $4 \mathrm{~h}$, final set occurred within $24 \mathrm{~h}$.

The stress-strain rate curves obtained from the viscometer (Figure 2) are typical of the performance of non-Newtonian fluids. The initial high rate of increase in stress with strain rate is followed by a slow reduction as strain rate is increased, and a relatively linear increase in stress with increasing strain rate is obtained. The data were used to compare the influence of the additives on grout performance by taking a single value of stress at a shear rate of $10 \mathrm{~s}^{-1}$ and calculating the resultant

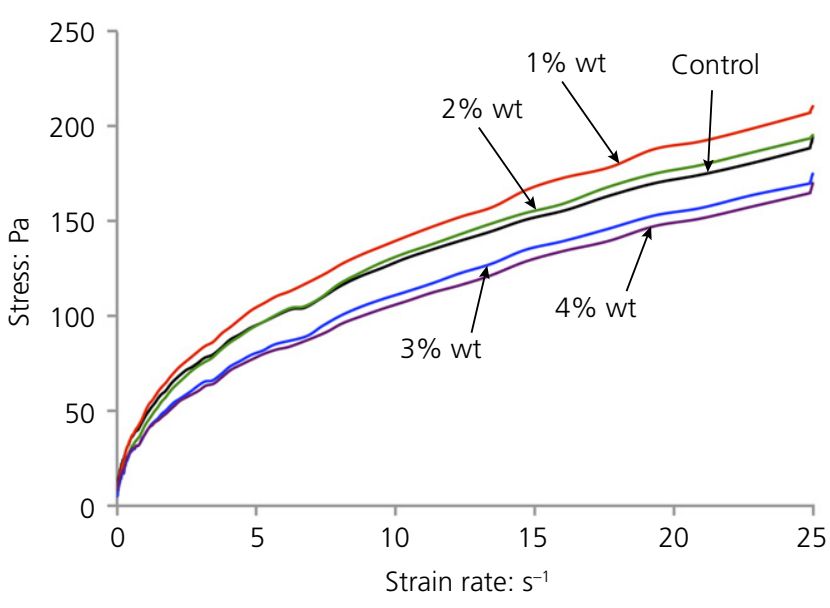

(a)

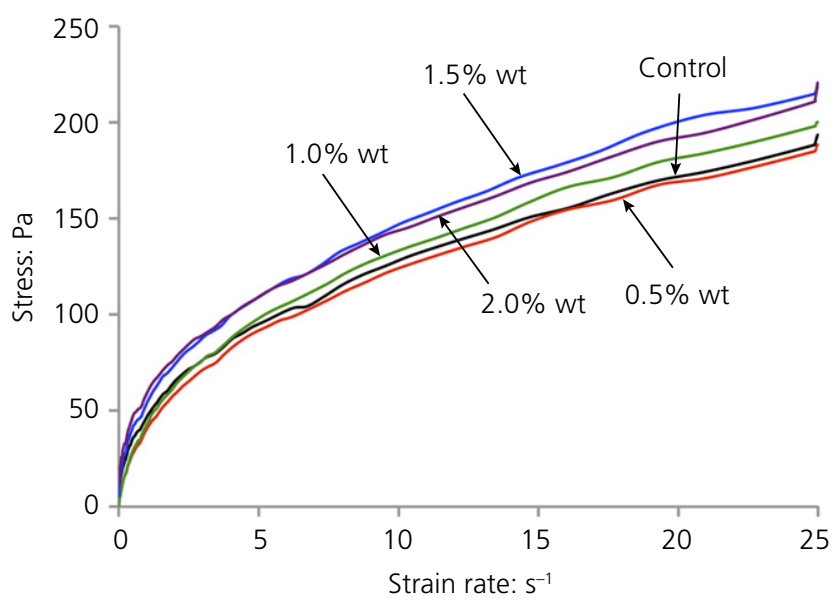

(b)

Figure 2. Viscometer results for grouts made with (a) sodium phosphate and (b) and sodium borate

apparent viscosity. The resultant stress and apparent viscosity data are displayed in Figure 3.

Because the apparent viscosities for both grouts were calculated from the stress at a shear rate of $10 \mathrm{~s}^{-1}$, the trends associated with viscosity were the same as those for stress. It was difficult to identify any consistent trends in the viscosity and stress data for the sodium borate grouts, although, apart from the stress and viscosity of the control grout being slightly higher than that of the $0.5 \%$ sodium borate grout and a slight reduction in both parameters from $1 \cdot 5 \%$ to $2 \cdot 0 \%$ addition level, the stress and viscosity of these grouts generally increased with addition level to a maximum at $1 \cdot 5 \%$. The sodium phosphate grouts showed an initial increase in both stress and viscosity up to a maximum at $1 \%$, followed by a decrease in both values with sodium phosphate addition level. The viscosities of the grouts peaked at $1.0 \%$ sodium phosphate and $1.5 \%$ sodium borate additions; this is likely to be due to the influence of the additions over the reaction between the cement powder and 


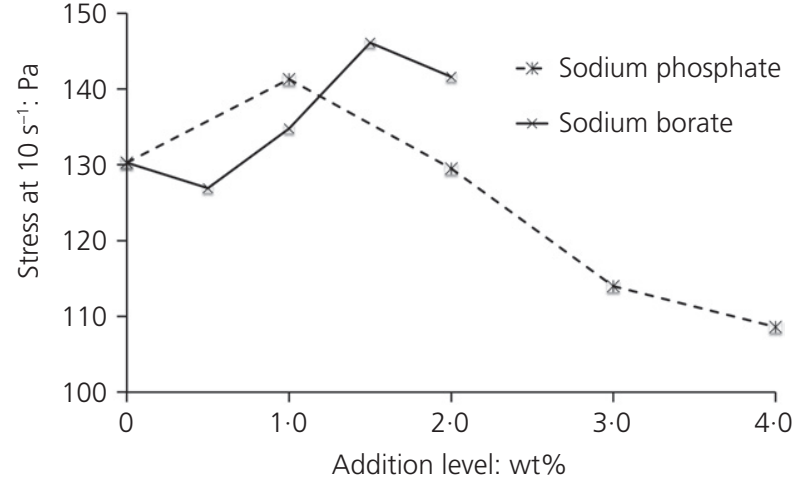

(a)

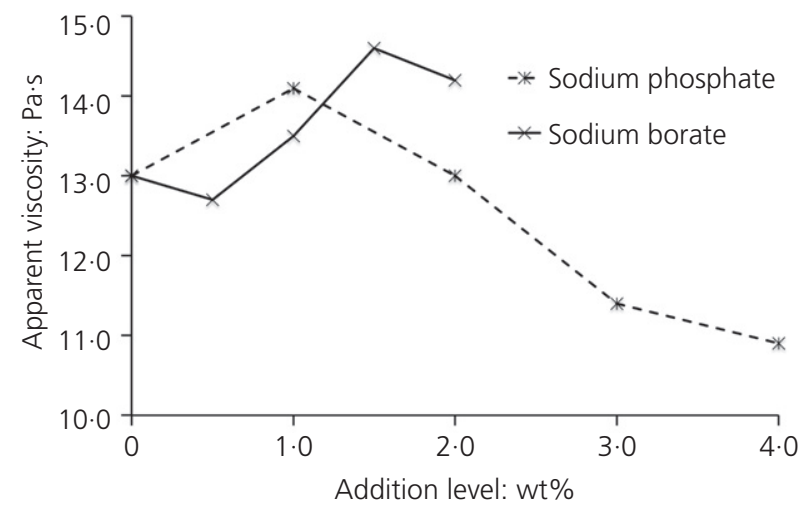

(b)

Figure 3. Plots of stress against addition level (a) and apparent viscosity against addition level (b)

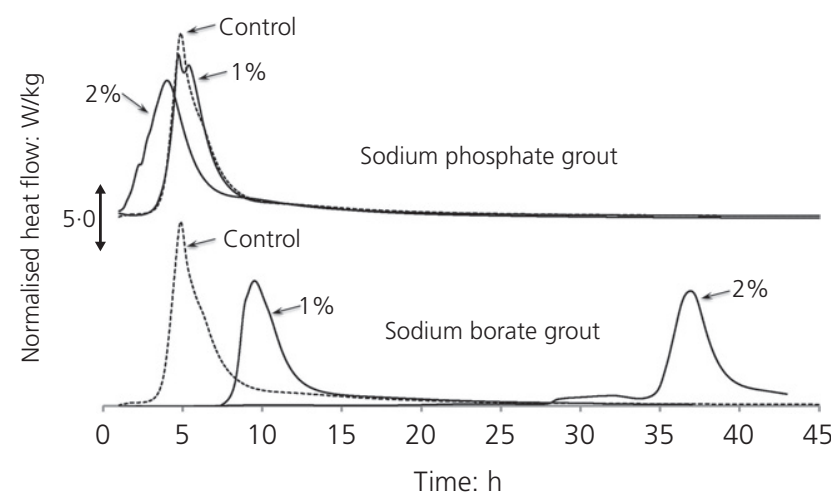

Figure 4. Calorimetry results the mix water. These results show that the effect of retarders on wet paste properties is complex and likely to be mostly of a non-physical nature. Any effects due to the change in water: solids ratio when adding increasing amounts of these retarders are likely to be minor because the addition level is small.

Calorimetry data showed how the retarders affected the times at which the cement hydration exotherms occurred. The calorimetry results are shown in Figure 4 and the main heat flow peaks are summarised in Table 4 . The results for the sodium borate grouts showed a distinct trend - the main heat flow peaks were retarded with a doubling of the amount of retarder added (time progressions of $4 \cdot 8,9 \cdot 3$ and $33.6 \mathrm{~h}$ for addition levels of 0,1 and $2 \%$ sodium borate, respectively). The magnitude of the main heat flow peak in the sodium borate grouts reduced as addition level increased (a magnitude progression of $13 \cdot 4,9 \cdot 1$ and $8 \cdot 3 \mathrm{~W} / \mathrm{kg}$ for addition levels of 0,1 and $2 \%$ respectively). These results demonstrate that the addition of sodium borate had a distinct influence on the magnitude of the main heat flow peak and the time at which it occurs.

The major heat flow peaks in the sodium phosphate grouts all occurred by $10 \mathrm{~h}$, with the addition level having little influence over when the main peaks occurred. There was only one main peak for the control grout $(13.4 \mathrm{~W} / \mathrm{kg}$ at $4.8 \mathrm{~h})$ whereas in the $1 \%$ sodium phosphate grout, the magnitude of the main peak was slightly reduced and the time at which it occurred was not affected $(12.0 \mathrm{~W} / \mathrm{kg}$ at $4.8 \mathrm{~h})$ and a second peak was produced $(11.2 \mathrm{~W} / \mathrm{kg}$ at $5.3 \mathrm{~h})$; this is likely due to enhanced hydration of the $\beta-\mathrm{C}_{2} \mathrm{~S}$ present in the class $\mathrm{G}$ cement, which is normally slower to hydrate than the $\mathrm{C}_{3} \mathrm{~S}$. Only one peak was recorded for the sample containing $2 \%$ sodium phosphate $(9.9 \mathrm{~W} / \mathrm{kg}$ at $3.8 \mathrm{~h}$ ), which occurred earlier than the peak for the control grout. These data suggest that phosphate can change from a retarder to an accelerator, as noted by Cau-dit-Coumes and Courtois (2003), although it is difficult to interpret the results.

\section{Hardened paste composition}

X-ray diffractograms of all samples are displayed in Figure 5 and show the crystalline phases present. The loss of weight from each sample, measured in TGA/DTG analysis and which is due to the decomposition of phases present, is summarised in Table 5 and these data were used to identify trends in the quantities of phases present.

Table 4. Summary of calorimetry data

\begin{tabular}{|c|c|c|c|c|c|c|c|c|c|c|}
\hline \multirow[b]{2}{*}{$\begin{array}{l}\text { Heat flow } \\
\text { event }\end{array}$} & \multicolumn{2}{|c|}{ Control } & \multicolumn{2}{|c|}{$1.0 \%$ sodium phosphate } & \multicolumn{2}{|c|}{$2.0 \%$ sodium phosphate } & \multicolumn{2}{|c|}{$1.0 \%$ sodium borate } & \multicolumn{2}{|c|}{$2.0 \%$ sodium borate } \\
\hline & $\begin{array}{l}\text { Heat flow: } \\
\text { W/kg }\end{array}$ & Time: $\mathrm{h}$ & $\begin{array}{l}\text { Heat flow: } \\
\text { W/kg }\end{array}$ & Time: $\mathrm{h}$ & $\begin{array}{l}\text { Heat flow: } \\
\text { W/kg }\end{array}$ & Time: $\mathrm{h}$ & $\begin{array}{c}\text { Heat flow: } \\
\text { W/kg }\end{array}$ & Time: $\mathrm{h}$ & $\begin{array}{l}\text { Heat flow: } \\
\text { W/kg }\end{array}$ & Time: $\mathrm{h}$ \\
\hline Peak 1 & $0 \cdot 2$ & 1.6 & $12 \cdot 0$ & $4 \cdot 8$ & $3 \cdot 7$ & $2 \cdot 2$ & $7 \cdot 6$ & 8.9 & 0.7 & $31 \cdot 5$ \\
\hline Peak 2 & $13 \cdot 4$ & $4 \cdot 8$ & $11 \cdot 2$ & $5 \cdot 3$ & $9 \cdot 9$ & $3 \cdot 8$ & $9 \cdot 1$ & $9 \cdot 3$ & $8 \cdot 3$ & $33 \cdot 6$ \\
\hline Peak 3 & 0.9 & $12 \cdot 5$ & 0.9 & $12 \cdot 1$ & $1 \cdot 4$ & $9 \cdot 6$ & a & a & a & a \\
\hline
\end{tabular}

${ }^{a}$ It was not possible to identify this heat event 


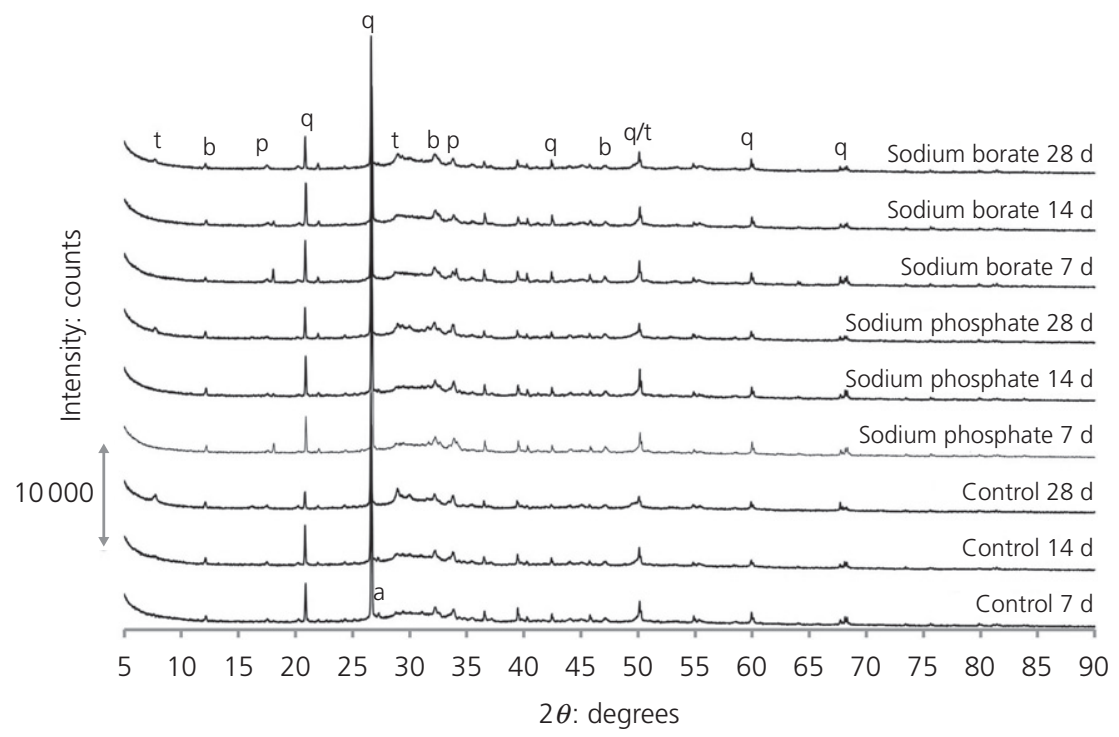

Figure 5. XRD diffractograms of all samples: $a, \alpha-\mathrm{C}_{2} \mathrm{SH}$; b, brownmillerite; $\mathrm{p}$, portlandite; q, quartz; t, tobermorite-11 nm

Table 5. TGA weight loss data

\begin{tabular}{|c|c|c|c|c|c|}
\hline & Dec & osition temperature range & hase responsible $f$ & omposition & \\
\hline & $\begin{array}{c}25-600^{\circ} \mathrm{C} \\
\text { Total CSH phases }{ }^{\mathrm{a}}: \mathrm{wt} \%\end{array}$ & $\begin{array}{c}25-100^{\circ} \mathrm{C} \\
\text { Main peak for CSH: wt \% }\end{array}$ & $\begin{array}{c}400-500^{\circ} \mathrm{C} \\
\text { Portlandite: wt } \%\end{array}$ & $\begin{array}{l}600-900^{\circ} \mathrm{C} \\
\text { Calcite: wt } \%\end{array}$ & $\begin{array}{l}25-1000^{\circ} \mathrm{C} \\
\text { Total: wt } \%\end{array}$ \\
\hline Control & & & & & \\
\hline $7 d$ & $11 \cdot 75$ & 3.62 & 1.95 & 0.48 & 14.47 \\
\hline $14 d$ & 11.90 & 3.57 & 1.97 & 0.46 & 14.73 \\
\hline $28 d$ & 12.91 & $4 \cdot 33$ & 1.56 & 0.56 & $15 \cdot 22$ \\
\hline Phospha & & & & & \\
\hline $7 d$ & $10 \cdot 58$ & $3 \cdot 51$ & 1.74 & 0.72 & $13 \cdot 23$ \\
\hline $14 d$ & $11 \cdot 60$ & 3.75 & 1.87 & 0.63 & $14 \cdot 36$ \\
\hline $28 d$ & $13 \cdot 45$ & $5 \cdot 54$ & 1.53 & 0.52 & 14.88 \\
\hline Borate $g$ & & & & & \\
\hline $7 d$ & $11 \cdot 54$ & $3 \cdot 75$ & 2.04 & 0.74 & $14 \cdot 51$ \\
\hline $14 d$ & $12 \cdot 24$ & $3 \cdot 81$ & $2 \cdot 12$ & 0.81 & $15 \cdot 49$ \\
\hline $28 d$ & 12.55 & 4.43 & 1.66 & 0.47 & $15 \cdot 63$ \\
\hline
\end{tabular}

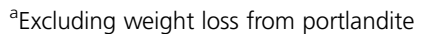

The XRD data show that reflections for the quartz in the silica flour (the main crystalline phase present in every sample) dominated the diffractograms, making it difficult to identify minor crystalline phases and associated trends. However, small reflections associated with the crystalline calcium silicate hydrate $(\mathrm{CSH})$ phases $\alpha-\mathrm{C}_{2} \mathrm{SH}\left(\mathrm{Ca}_{2}\left(\mathrm{SiO}_{4}\right) \mathrm{H}_{2} \mathrm{O}\right)$ and tobermorite-1.1 nm $\left.\left(\mathrm{Ca}_{5} \mathrm{Si}_{6}(\mathrm{OH})_{18}\right)\right)$, portlandite $\left(\mathrm{Ca}(\mathrm{OH})_{2}\right)$ and brownmillerite $\left(\mathrm{Ca}_{2} \mathrm{FeAl}_{2} \mathrm{O}_{5}\right.$, an unhydrated relic from the cement) were identified. The intensities of the quartz reflections decreased with curing time as the quartz reacted with calcium, as reported in the literature (Bensted, 2008; Nelson and Guillot, 2006). The strongest reflections for portlandite at $2 \theta=18.09^{\circ}$ and $34.09^{\circ}$ decreased in intensity with curing time as the portlandite reacted with the quartz. In previous work carried out by the authors using organic retarders, only amorphous portlandite was identified (Collier et al., 2015b, 2016). The main reflections for tobermorite- $1 \cdot 1 \mathrm{~nm}$ were evident, although their intensities were very low, so it was difficult to confirm whether these increased with curing time (particularly in the control sample). The most intense reflection for $\alpha-\mathrm{C}_{2} \mathrm{SH}$ was only identified in the $7 \mathrm{~d}$ control sample and it was absent by $14 \mathrm{~d}$, which is in line with information reported in the literature (Nelson and Guillot, 2006). Weak reflections for brownmillerite were present at all ages, indicating little reaction during curing. Comparing the XRD traces of the grouts containing either retarder with those of the control sample suggests that the retarders may suppress the formation of crystalline CSH phases. In similar work with commonly used 

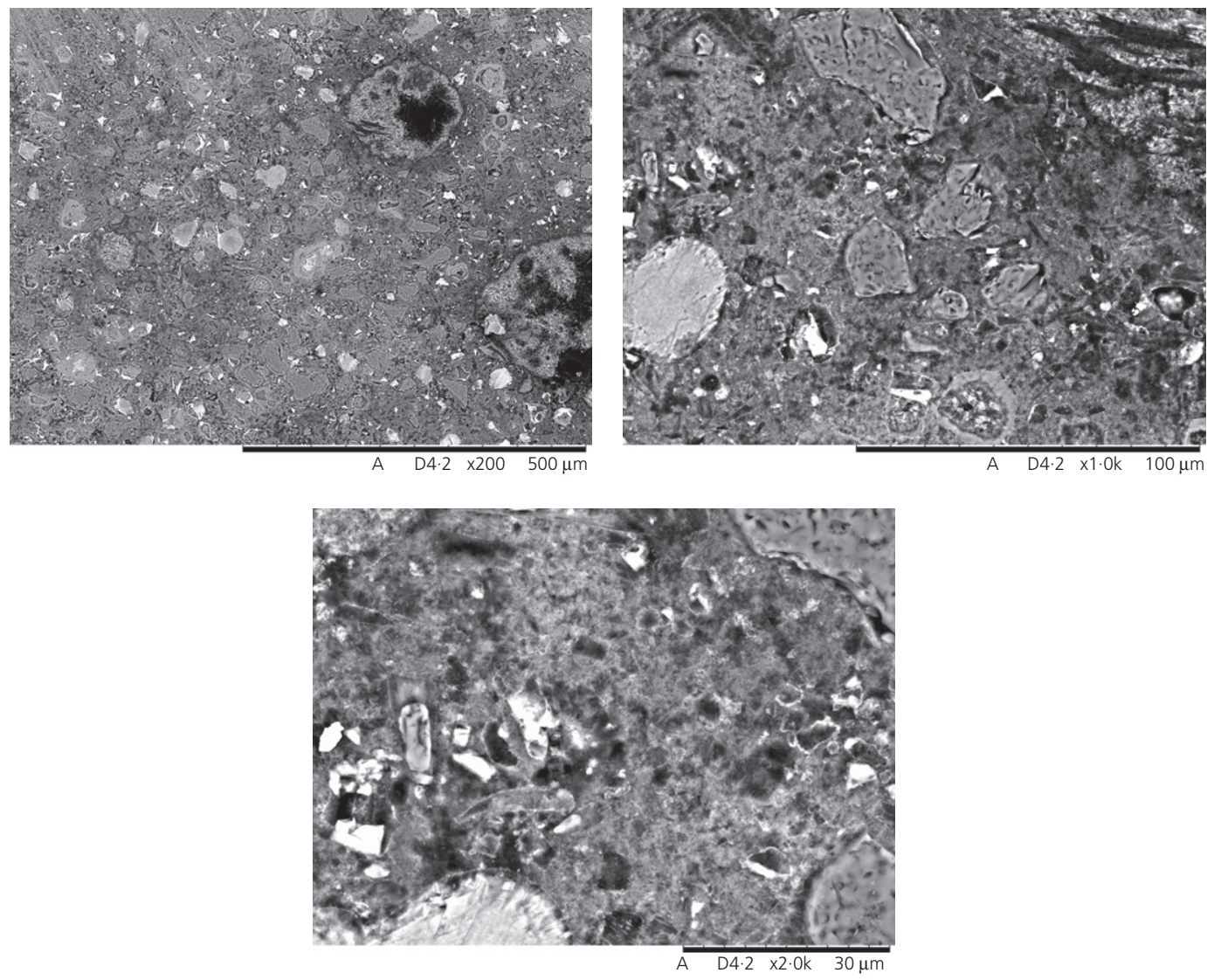

Figure 6. SEM BEI micrographs of grout containing $2 \%$ sodium borate

organic retarders, the authors found that the formation of crystalline CSH phases was not affected by the retarders (Collier et al., 2015b, 2016).

Thermal analysis data show that the total weight loss for each type of sample increased with curing time, demonstrating ongoing formation of $\mathrm{CSH}$ phases. These phases are formed from both the hydration of calcium silicates in the cement as well as from the reaction between the calcium phases formed from the cement hydration (portlandite) and the quartz in the silica flour (Bensted, 2008; Nelson and Guillot, 2006). Portlandite content increased slightly between $7 \mathrm{~d}$ and $14 \mathrm{~d}$, but by $28 \mathrm{~d}$ had reduced, likely to be due to a slow reaction with the quartz. A small quantity of calcite $\left(\mathrm{CaCO}_{3}\right)$ was present in each sample, probably formed from the carbonation of portlandite during sample preparation, or as a relic from the cement. It was difficult to identify any trends associated with the effect of either retarder from the TGA/DTG results.

\section{Microstructural/elemental characteristics}

Photomicrographs were obtained by backscattered electron imaging (BEI) of all samples at a range of magnifications. Examples obtained for the sodium borate grouts are shown in
Figure 6. Areas of black on the micrographs represent pore space, while the brighter areas signify particles containing elements with a higher atomic number. A qualitative assessment of the micrographs showed there was very little difference in porosity or microstructural density due to either retarder when compared with the control samples.

An EDX scan of each sample showed that calcium $(\mathrm{Ca})$, silicon $(\mathrm{Si})$, oxygen $(\mathrm{O})$ and aluminium $(\mathrm{Al})$ were the main elements present, with minor amounts of potassium $(\mathrm{K})$, sodium $(\mathrm{Na})$, iron $(\mathrm{Fe})$ and magnesium $(\mathrm{Mg})$. Small peaks for phosphorus $(\mathrm{P})$ were detected in the sodium phosphate samples and even smaller peaks for boron (B) in each sodium borate sample, although this should be treated with caution because the boron was at the threshold of detection with the equipment used.

Elemental EDX maps were obtained at $\times 2000$ magnification to study the distribution of elements. As an example, Figure 7 shows the data for the $2 \%$ sodium borate sample. The data show mainly calcium, silicon and oxygen from the CSH binder phases present, but it was not possible to differentiate between the different $\mathrm{CSH}$ phases, either by visual interpretation of the 

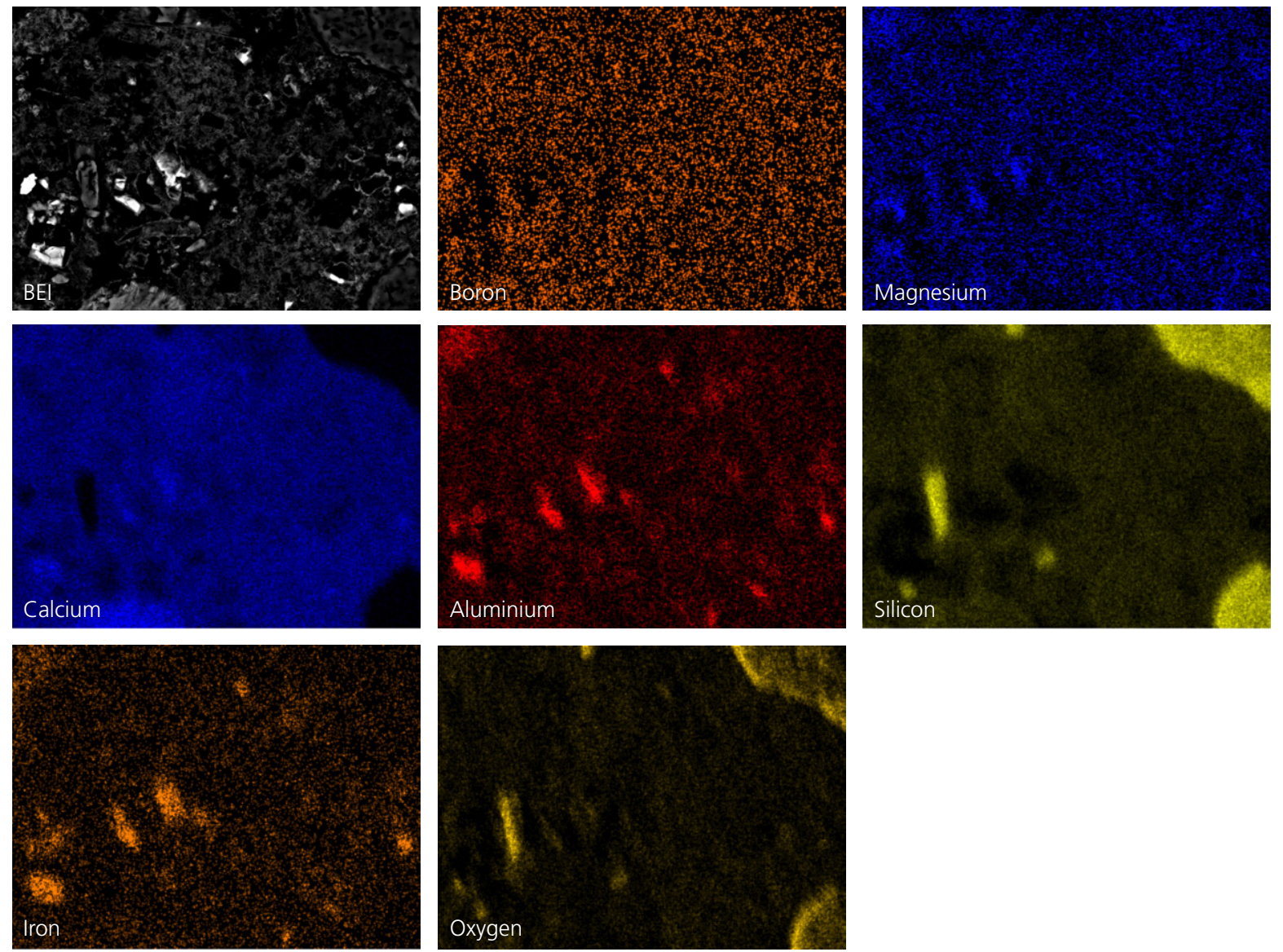

Figure 7. Elemental EDX maps of grout containing $2 \%$ sodium borate

micrographs or from the EDX data. Within the main matrix of each sample, other particles were embedded. Areas where calcium, aluminium and iron were coincident (e.g. in the lower left-hand corner of Figure 7) indicate the presence of what is likely to be unhydrated brownmillerite. Similarly, areas rich in silicon and oxygen only, such as those in the upper and lower right-hand corners in Figure 7, are likely to be particles of silica flour. All samples showed the presence of silica particles like this, which, combined with the XRD results, demonstrates that not all the silica had reacted by $28 \mathrm{~d}$. However, the presence of darker areas within these particles shows there may be some dissolution/reaction, likely to be from the reaction with the calcium in the cement to form $\mathrm{CSH}$ phases. There were also areas in each sample that were rich in calcium only and these are likely to be portlandite. Although not shown here, both phosphorus and boron were generally well distributed in each sample, which suggests that no new borate or phosphate phases were forming.

Despite careful qualitative analysis of the SEM/EDX results, identification of any microstructural characteristics specific to sample type was not possible.

\section{Discussion}

There is little reported work on the mechanism of retardation associated with borate and phosphate ions in cement pastes, and the work there is was performed under atmospheric conditions. Most researchers have reported that when phosphate is dissolved in grout mix water, the paste induction period is increased, leading to an overall decrease in hydration rate and a delay in setting time. Depending upon the concentration and phosphate type, this delay can be up to several days (Bénard et al., 2005, 2008; Cau-dit-Coumes and Courtois, 2003; Lieber, 1974; Ltifi et al., 2011; Ma and Brown, 1994). This may be due to the adsorption of phosphate ions onto the cement particles, reducing or inhibiting dissolution of the cement. However, beyond a certain phosphate concentration, retardation does not occur, and Cau-dit-Coumes and Courtois (2003) and Ma and Brown (1994) observed that, at high concentrations ( $>25 \mathrm{~g} / \mathrm{l}$ of grout mix water), the setting time was reduced. Summarising this, Bénard et al. (2005) suggested that adsorption of phosphate ions onto cement particles occurs at low concentrations but, when the concentration exceeds $25 \mathrm{~g} / \mathrm{l}$, precipitation of calcium phosphate (hydroxyapatite) on the cement surface becomes predominant, leading to an increase 
in hydration and early paste stiffening. The consistency results obtained in the current study (and to some degree the stress and viscosity results) display trends that appear to change according to the addition level. The phosphate level where the effect on grout thickening changes from retardation to acceleration equates to an addition level of $\sim 1.25 \%$ ( $25 \mathrm{~g} / 1$ of mix water) (Cau-dit-Coumes and Courtois, 2003). The results from this study are in agreement, with a change in consistency and viscosity noted at addition levels around $1-2 \%$. Borate ions react with cement to form calcium borate phases, which are adsorbed onto cement particles to precipitate slightly soluble layers over the cement, thus preventing the usual cement hydration (Atabek et al., 1992; Bell and Coveney, 1998; Bensted et al., 1991; Csetenyi and Glasser, 1995; Demirbas and Karslioglu, 1995; Ramachandran and Lowery, 1998). This coating of particles suggests that the mechanism by which these inorganic compounds retard hydration differs from how organic compounds retard, which is largely based on complexation of calcium from the cement (Taylor, 1997).

Both of the borate and phosphate compounds studied in this work (i.e. sodium borate and sodium phosphate) were found to influence wet paste properties and both retarded grout thickening at $90^{\circ} \mathrm{C}$ or $120^{\circ} \mathrm{C}$ and $50 \mathrm{MPa}$, with sodium borate more effective. For each retarder, there was found to be an addition level beyond which the initial consistency became too high. It was not possible to add enough sodium phosphate to retard the time for the grout to reach $70 \mathrm{Bc}$ to beyond $4 \mathrm{~h}$, whereas sodium borate achieved this at $90^{\circ} \mathrm{C}$ and nearly achieved it at $120^{\circ} \mathrm{C}$. All successfully retarded grouts set within $24 \mathrm{~h}$, providing confidence that waste package deployment rates of the order of one per day could be achievable. The combination of sodium borate and sodium phosphate provided sufficient retardation at $120^{\circ} \mathrm{C}$, but the initial grout consistency was greater than $70 \mathrm{Bc}$ and so would be too thick for DBD. There appears to be an optimum retarder addition level at which the highest plastic viscosity and yield stress is achieved. It is unlikely that the influence of the additives on the water:solids ratio would affect retardation because the quantity added was very small. Calorimetry results corroborated the consistency data in that the sodium borate was found to be better retarder than the sodium phosphate. These results demonstrate that the influence of the retarders is complex and difficult to understand, as noted elsewhere (Shariar, 2011).

The hardened paste composition was unaffected by the retarders and the phases present were typical of class $G$ cement/ silica flour systems. The reaction of quartz was slow, with $\alpha-\mathrm{C}_{2} \mathrm{SH}$ forming early in the hydration and replaced by tobermorite- $1 \cdot 1 \mathrm{~nm}$ at $7 \mathrm{~d}$ (Bensted, 2008; Nelson and Guillot, 2006). Both retarders appeared to suppress or hinder the formation of the crystalline CSH phases, but the low intensity of the XRD reflections makes this difficult to confirm. This effect has not been reported previously as most retarders act early in hydration before the paste starts to thicken. Organic retarders complex calcium, partly preventing the formation of portlandite, so the presence of portlandite in the samples in this study shows that the inorganic retarders studied work differently.

This work has permitted an assessment of whether these retarders are appropriate for use in DBD. The addition of $\geq 0.75 \%$ sodium borate provided sufficient retardation for use at $90^{\circ} \mathrm{C}$, and the grout produced remained sufficiently fluid to flow around emplaced waste packages and set within the desired time. The use of $1 \%$ sodium borate provided almost sufficient retardation at $120^{\circ} \mathrm{C}$, but increasing the addition to $2 \%$ produced a grout too thick to test, meaning it could not be pumped. The addition of only sodium phosphate did not retard sufficiently at any temperature, but it can be used in conjunction with sodium borate ( $2 \%$ of each) to delay the attainment of $70 \mathrm{Bc}$ for $>4 \mathrm{~h}$; however, this grout would be too thick to pump. Temperature and pressure greatly influence the grout hydration rate. In DBD, the ambient downhole temperature will depend on the depth and the local geothermal environment, but could exceed $120^{\circ} \mathrm{C}$ (Best, 2003). This means that while sodium borate is appropriate for use at lower temperatures, it cannot be considered across the whole range of borehole depths. The phase composition of the hardened grouts was similar to that of hardened well cements that have demonstrated durability over $\sim 60$ years. The groundwater in DBD will contain chlorides, but considerable quantities of chlorides and carbonates are present in hydrocarbon and geothermal wells, so the local geochemistry in either of the latter will be more chemically aggressive than in DBD, meaning that the durability of DBD grouts is likely to be higher.

It is important to accurately replicate downhole conditions during experimentation. Consistency testing best represents DBD temperature and pressure, but these conditions are difficult to replicate when investigating properties such as viscosity and yield stress. Specialised high-temperature and highpressure equipment capable of investigating grout rheology is now available, but it is expensive and only appears to be used by testing laboratories that perform regular studies on grouts. Using calorimetry at elevated temperature $\left(85^{\circ} \mathrm{C}\right.$ in this case) provides information on the retardation of hydration reactions, but the time taken for the sample to equilibrate with the test temperature $(\sim 1 \mathrm{~h})$ means that much information on early reactions is not obtained. It is also very difficult to investigate hydration reactions using calorimetry at elevated pressure, and there is no readily available equipment for this on the market.

\section{Conclusions}

The following conclusions can be drawn from this work.

- The addition of sodium borate $0.75 \%$ can provide the level of retardation required for deep borehole disposal (DBD) at $90^{\circ} \mathrm{C}$. At $120^{\circ} \mathrm{C}$, the addition of $1 \%$ provided almost enough retardation. 
Sodium phosphate did not provide sufficient retardation at either test temperature.

- The influence of sodium borate or sodium phosphate on rheological performance is difficult to interpret, but the calorimetry results demonstrated that the sodium borate retarded the main hydration reaction more than the sodium phosphate.

- In all grouts where retardation was greater than $4 \mathrm{~h}$, final set was achieved within $24 \mathrm{~h}$.

- The additives did not influence the phases formed after $28 \mathrm{~d}$ hydrothermal curing. The phases present in the hardened cement pastes match those reported in the literature, where durability has been demonstrated at temperatures and pressures similar to those in DBD. The use of either retarder appeared to suppress the formation of crystalline $\mathrm{CSH}$ phases over $28 \mathrm{~d}$ curing, but did not affect the formation of crystalline portlandite.

This work has demonstrated that thickening of cementitious grouts similar to those used in oil well and geothermal energy applications can be retarded using sodium borate and the pastes produced would be suitable as sealing and support matrices in DBD up to $90^{\circ} \mathrm{C}$. However, the performance of these inorganic materials was found to be inferior to that of organic retarders, which provide the desired thickening retardation across the whole DBD temperature range.

\section{Acknowledgements}

This work was financially supported by the UK Engineering and Physical Science Research Council (grant EP/K039350/1. The research was performed in part at the Midas Facility of The University of Sheffield, which was established with support from the Department of Energy and Climate Change. Our thanks go to Cebo UK Ltd for the cement, Minerals Marketing Ltd for the silica flour, Sika Ltd for some of the additives and Professor Fergus Gibb for assistance in manuscript preparation.

\section{REFERENCES}

API (American Petroleum Institute) (2010) API Specification 10A: Specification for Cements and Materials for Well Cementing, 24th edn. API, Washington, DC, USA.

Arliguie G, Ollivier JP and Grandet J (1982) Etude de l'effet retardateur du zinc sur l'hydratation de la pate de ciment Portland. Cement and Concrete Research 12(1): 79-86 (in French).

Arnold B, Brady P, Altman S et al. (2013) Deep Borehole Disposal Research: Demonstration Site Selection Guidelines, Borehole Seals Design and $R D \& D$ Needs. Sandia National Laboratories, USA. Report for U.S. Department of Energy, FCRD-USED-2013000409, SAND2013-9490P.

ASTM (2013) C 191-13: Standard test methods for time of setting of hydraulic cement by Vicat needle. ASTM International, West Conshohocken, PA, USA.

ASTM (2016) C 150/C 150M: Standard specification for Portland cement. ASTM International, West Conshohocken, PA, USA.
Atabek R, Bouniol P, Vitorge P, Le Bescop P and Hoorelbeke JM (1992) Cement use for radioactive waste embedding and disposal purposes. Cement and Concrete Research 22(2-3): 419-429.

Banfill PFG (1986) Precipitation of calcium hydroxide in the presence of organic compounds. Journal of Materials Science Letters 5(1): 33-34.

Bell IS and Coveney P (1998) Molecular modelling of the mechanism of action of borate retarders on hydrating cements at high temperature. Molecular Simulation 20(6): 331-356.

Bénard P, Garrault S, Nonat A and Cau-Dit-Coumes C (2005) Hydration process and rheological properties of cement pastes modified by orthophosphate addition. Journal of the European Ceramic Society 25(11): 1877-1883.

Bénard P, Garrault S, Nonat A and Cau-Dit-Coumes C (2008) Influence of orthophosphate ions on the dissolution of tricalcium silicate. Cement and Concrete Research 38(10): 1137-1141.

Bensted J (2008) Development with oilwell cements. In Structure and Performance of Cements (Bensted $\mathbf{J}$ and Barnes $\mathbf{P}$ (eds)), 2nd edn. Spon Press, London, UK, pp. 237-252

Bensted J, Callaghan IC and Lepre A (1991) Comparative study of the efficiency of various borate compounds as set-retarders of class $\mathrm{G}$ oilwell cement. Cement and Concrete Research 21(4): 663-668.

Best MG (2003) Igneous and Metamorphic Petrology. Blackwell Science, Malden, MA, USA.

Beswick J, Gibb F and Travis K (2014) Deep borehole disposal of nuclear waste: engineering challenges. Proceedings of the Institution of Civil Engineers - Energy 167(2): 47-66, http://dx.doi.org/ 10.1680/ener.13.00016.

Bourbon X and Toulhoat P (1996) Influence of organic degradation products on the solubilisation of radionuclides in intermediate and low level radioactive wastes. Radiochimica Acta 74(s1): 315-319.

BSI (2009) BS EN ISO 10426-1:2009: Petroleum and natural gas industries, cements and materials for well cementing, specification. BSI, London, UK.

Cau-dit-Coumes C and Courtois S (2003) Cementation of a low-level radioactive waste of complex chemistry investigation of the combined action of borate, chloride, sulfate and phosphate on cement hydration using response surface methodology. Cement and Concrete Research 33(3): 305-316.

Chapman N and Gibb F (2003) A truly final waste management solution: is very deep borehole disposal a manageable solution for high-level wastes or fissile materials? Radwaste Solutions 10(4): 26-37.

Collier NC, Sharp JH, Milestone NB, Hill J and Godfrey IH (2008) The influence of water removal techniques on the composition and microstructure of hardened cement pastes. Cement and Concrete Research 38(6): $394-400$.

Collier NC, Travis KP, Gibb FGF and Milestone NB (2015a) Cementitious grouts for disposal of nuclear wasteforms in deep boreholes. Proceedings of American Nuclear Society International High-Level Radioactive Waste Management Conference, Charleston, SC, USA, American Nuclear Society, La Grange Park, IL, USA, pp. 394-400.

Collier NC, Travis KP, Gibb FGF and Milestone NB (2015b) Characteristics of cementitious paste for use in deep borehole disposal of spent fuel and high level wasteforms. Scientific Basis for Nuclear Waste Management XXXVIII, Materials Research Society Symposium Proceedings, Materials Research Society, Cambridge, UK, vol. 1744: 205-210.

Collier NC, Milestone NB, Travis KP and Gibb FGF (2016) The effect of organic retarders on grout thickening and setting during deep borehole disposal of high-level radioactive waste. Progress in Nuclear Energy 90: 19-26, https://doi.org/10.1016/j.pnucene.2016. 02.021 . 
Csetenyi LJ and Glasser FP (1995) Borate retardation of cement set and phase relations in the system $\mathrm{Na}_{2} \mathrm{O}-\mathrm{CaO}-\mathrm{B}_{2} \mathrm{O}_{3}-\mathrm{H}_{2} \mathrm{O}$. Advances in Cement Research 7(25): 13-19, http://dx.doi.org/ 10.1680/adcr.1995.7.25.13

Demirbas A and Karslioglu S (1995) The effect of boric acid sludges containing borogypsum on properties of cement. Cement and Concrete Research 25(7): 1381-1384.

Gibb FGF (2010) Looking down the bore - radioactive waste management: deep boreholes. Nuclear Engineering International, February: pp. 21-22.

Gibb F, McTaggart N, Travis K, Burley D and Hesketh K (2008) Highdensity support matrices: key to the deep borehole disposal of spent nuclear fuel. Journal of Nuclear Materials 374(3): 370-377.

Glasser FP (1992) Progress in the immobilization of radioactive wastes in cement. Cement and Concrete Research 22(2-3): 201-216.

Glasser FP (1993) Chemistry of cement solidified waste forms. In Chemistry and Microstructure of Solidified Waste Forms (Spence RD (ed.)). Lewis Publishers, London, UK, pp. 1-40.

Hakanen M and Ervanne H (2006) The Influence of Organic Cement Additives on Radionuclide Mobility. A Literature Survey. Posiva, Olkiluoto, Finland, Working report 2006-06.

Jupe A, Wilkinson A, Luke K and Funkhouser G (2008) Class H cement hydration at $180^{\circ} \mathrm{C}$ and high pressure in the presence of added silica. Cement and Concrete Research 38(5): 660-666.

Lieber W (1974) The influence of phosphates on the hydration of Portland cement. Proceedings of the 6th International Congress on the Chemistry of Cement, Moscow, USSR.

Ltifi M, Guefrech A and Mounanga P (2011) Effects of sodium tripolyphosphate addition on early-age physico-chemical properties of cement pastes. Procedia Engineering 10: 1457-1462, https://doi.org/10.1016/j.proeng.2011.04.242.

Ma W and Brown PW (1994) Effect of phosphate additions on the hydration of Portland cement. Advances in Cement Research 6(21) 1-12, http://dx.doi.org/10.1680/adcr.1994.6.21.1.
Nelson E and Guillot D (eds) (2006) Well Cementing, 2nd edn. Schlumberger, Houston, TX, USA.

Odler I (2004) Hydration, setting and hardening of Portland cement. In Lea's Chemistry of Cement and Concrete (Hewlett PC (ed.)), 4th edn. Elsevier Science and Technology, London, UK, pp. 241-297.

Ramachandran VS and Lowery MS (1998) Conduction calorimetric investigation of the effect of retarders on the hydration of Portland cement. Thermochimica Acta 195: 373-387, https://doi.org/ 10.1016/0040-6031(92)80081-7.

Scherer G, Funkhouser G and Peethamparan S (2010) Effect of pressure on early hydration of class $\mathrm{H}$ and white cement. Cement and Concrete Research 40(6): 845-850.

Shariar A (2011) Investigation on Rheology of Oil Well Cement Slurries. $\mathrm{PhD}$ thesis, The University of Western Ontario, London, ON, Canada.

Shariar A and Nehdi M (2014) Rheological properties of oil well cement slurries. Proceedings of the Institution of Civil Engineers Construction Materials 165(1): 25-44, http://dx.doi.org/10. 1680/coma.2012.165.1.25.

Taylor HFW (1997) Cement Chemistry, 2nd edn. Thomas Telford, London, UK.

Thomas NL, Jameson DA and Double DD (1981) The effect of lead nitrate on the early hydration of Portland cement. Cement and Concrete Research 11(1): 143-153.

Wilding CR, Walter A and Double D (1984) A classification of inorganic and organic admixtures by conduction calorimetry. Cement and Concrete Research 14(2): 185-194.

Young JF (1972) A review of the mechanisms of set-retardation in Portland cement pastes containing organic admixtures. Cement and Concrete Research 2(4): 415-433.

Zhang J, Weissinger E, Peethamparan S and Scherer G (2010) Early hydration and setting of oil well cement. Cement and Concrete Research 40(7): 1023-1033. 